\title{
CORRESPONDENCE
}

\section{CONTRAST MEDIA IN ORBITAL RADIOGRAPHY}

\section{To the Editorial Committee of the British JouRnal of OpHTHALMOLOGY,}

SiRs-The paper presented by Cowie and Groves (1955) is a most interesting contribution.

Having been impressed with the serious dangers of Diodrast (the American form of Diodone), I wish to discuss the reasons why the potential complications from its injection behind the eye outweigh its value as a diagnostic aid. Venospasm and thrombosis, as well as sclerosing lipogranuloma have been reported with the use of Diodrast. Fatalities of an anaphylactic nature have been seen. Subcutaneous injection sometimes results in a tissue slough.

Dr. José Bonmatie and I performed animal experiments with 35 per cent. Diodrast (soon to be reported in the Journal of Roentgenology, Radium Therapy, and Nuclear Medicine). Although much of the dye was absorbed one hour after an orbital injection. a trace was still evident at the end of 3 hours. In rabbits, retrobulbar injection of only two ml. 35 per cent. Diodrast produced marked oedema and cellulitis of the orbit with an associated exposure keratitis. The most striking complication was actual necrosis of the sclera in many rabbits receiving only $1 \mathrm{ml}$. Some others given $2 \mathrm{ml}$. of the dye revealed extensive necrosis of the sclera, and actual rupture through into the eye.

Cadaver injections demonstrated a leak through of the dye from the orbit into the middle cranial fossa.

Sometimes the opaque medium did not spread evenly through the tissue compartments of the living orbit; consequently, false tumour shadows appeared. Indeed, one patient with unilateral exophthalmos was given an injection of 35 per cent. Diodrast with hyaluronidase, and there appeared a rounded area devoid of dye which seemed to represent a definite tumour. At operation, the orbit was extensively explored, but no mass was found.

One of the most frightening complications which I have seen from the injection of $\mathbf{5 0}$ TRU hyaluronidase and $5 \mathrm{ml} .35$ per cent. Diodrast into the central surgical space was spasm of the central retinal artery. A few minutes after the injection, the vision had fallen from $20 / 20$ to no perception of light. The retinal arteries were extremely narrow and there was obvious segmentation of blood in the veins. The vision gradually returned to $20 / 20$ within the following 24 hours, and the fundus picture was then normal. No further orbital injections of Diodrast have been performed since this last complication was encountered.

Respectfully yours,

ThOMAS MANCHESTER

478, Peachtree Street, N.E.,

Atlanta 3, Ga.

June 20, 1955.

\section{REFERENCE}

CowIE, J. W., and Groves, J. S. (1955). British Journal of Ophthalmology, 39, 283. 